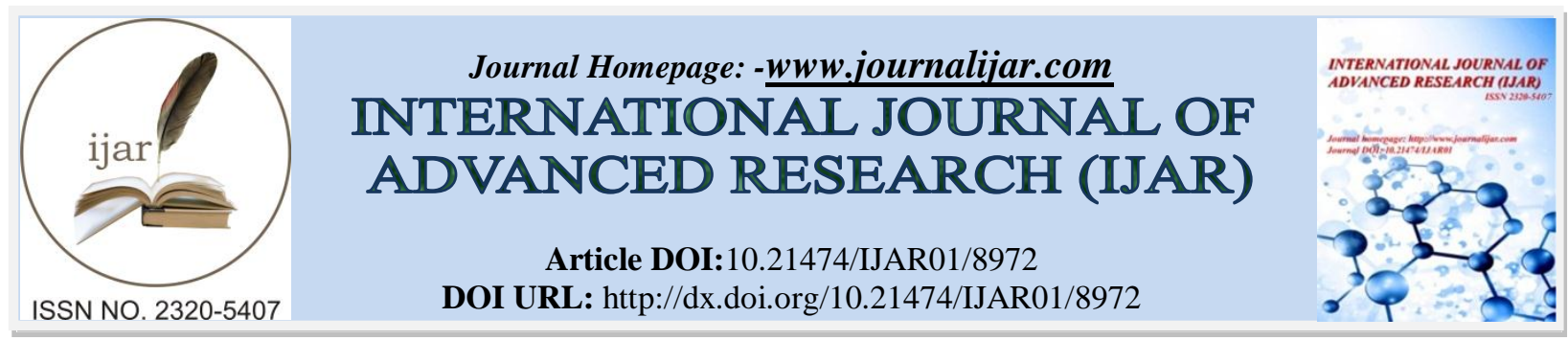

RESEARCH ARTICLE

\title{
CITIZENS PARTICIPATION IN GOOD GOVERNANCE OF PAKISTAN.
}

\section{Dr. Mustafa Hyder ${ }^{1}$, Dr. Shahid Zaheer Zaidi ${ }^{1}$ and Ms. Sameen Mustafa ${ }^{2}$.}

1. Assistant Professor, Department of Public Administration University of Karachi.

2. Institute of Business Administration (IBA), Karachi.

\section{Manuscript Info}

Manuscript History

Received: 24 February 2019

Final Accepted: 26 March 2019

Published: April 2019

Key words:-

Citizen Participation, Citizen rights, Citizen duties, Governance, Participated governance.

\begin{abstract}
This paper presents the key aspects of the citizen in the role of good governance. Citizen participation has become an essential component in the development process of a country. They are the voice of the nation that makes efforts to improve the country. They represent the hopes, aspirations and the interests of every other individual for the betterment of the state.

The methodology consists of primary data gathered through a survey in which a questionnaire with closed ended questions. This widely validated questionnaire was used to collect data from people of different ages, education and ethnicity. The sample size was 1000 respondents selected via judgmental sampling. The research highlights the key challenges faced by the citizens. Purpose of this work is to establish the importance of the factor 'Role of a Citizen', to discuss the potential and future development of a country. Other than, the aim is to determine what means/tools they use to promote the good governance of a country. Our objective is to analyse the impact of citizens in the Governance of Pakistan; and to propose possible ways to deal with the issues involved in it. This research tries to conclude the fact that, in the current economy, citizens are considered to be the main competitive advantage and most important asset for the prosperity of a country.
\end{abstract}

Copy Right, IJAR, 2019,. All rights reserved.

\section{Introduction:-}

Lack of citizen participation is an important issue in Pakistan. It is said that citizens are central to good governance that's why it is very important to strengthen the relationship between citizens and government. In countries where there is no stable relationship between citizens and government end up facing impeachment of a President, numerous major corruption scandals and investigations being opened into the conduct of high-ranking political officials. This is reinforcing the belief that those in power operate to a different set of rules that are focused on selfinterest rather than public good. So, it is extremely important for citizens to raise their voices for their rights and held pressure on government to perform well. Good governance, transparency and accountability are not attainable until citizens participate in governance process.

\section{Scope}

The study is based upon participation of 1000 respondents but the citizens are in billions. Besides the general idea about citizen participation, and studies and researches proving its importance, the research also covers the ways how citizens could incorporate their participation. 


\section{Objectives of the Study}

1. To find out the variables that is affecting citizen participation in governance

2. To find out the citizens satisfaction towards government officials

3. To discover ways for incorporating citizen participation in governance

\section{Problem Statement}

The general purpose of the study is to understand the connection between citizens and good governance. Whether citizen participation in governance is necessary or not? To what extent should citizens interfere in governance? Does citizen participation lead to good governance? How should they participate and what factors affect their participation?

\section{Literature Review}

Good governance or its absence is a central theme in Pakistan. For the state to perform efficiently, good governance is needed at all levels. The existence of institutional clashes, lack of accountability,massive corruption, constitutional crisis,poor law and order conditions, is ample evidence of poor governance in the country.Since we achieved independence, Pakistan has been faced by political instability and unrest which has created a black hole in the country's economic development and progress. Good governance cannot be established with the presence of political disorder and power-hungry politicians. But these power-hungry politicians could be controlled if citizens keep them accountable for their actions. If public officials have a fear to be answerable before public they would do their job with honesty. Public participation in political decisionmaking is crucial to good governance. Co-operation and public support hold great importance in good governance. It covers the way for good governance.

\section{Citizens have the right to elect competitive and capable politicians:}

The most important right of citizens is electing good, qualified and deserving politicians. Citizens must use their voting power very wisely; this is the first step towards good governance. Citizens shouldn't be biased in voting or vote on the basis of sectarian differences or language, vote is the responsibility of citizens which must be used fairly.

\section{Citizens can participate in policy making:}

Citizens affected by public problems are relevant actors in the policy-making process. They could raise their voices by getting a large group of people behind; it will be easier to persuade politicians to listen and make the policy to solve their problems. Also, through media and lobbying many citizens have the opportunity to influence the public policy of a nation. Moreover, participation of citizens in policy making gives government new ideas, information and resources when making decisions.

\section{Citizens should keep an eye on public officials:}

Also, citizens shouldn't trust the government blindly; they must keep an eye on government. They should have knowledge about their rights and country's constitution so they can hold government responsible if anything goes against it. Citizens' access to information is vital for the promotion of democracy, rule of law, human rights, and transparency and entrenching accountability in the state. Without accountability, rule of law, respect for human rights and democracy, the quality of governance would decline. The respective responsibilities and roles of the government (making a decision for which it will be held accountable and on the basis of which its performance may be judged) and the citizen (providing input for the decision-making process) must be clear and obvious too. Citizens are not government; they elect it and want to be served by it. But if they want to participate more than just via the ballot box, then they need proper access to information, opportunities and consultation and to take an active part in policymaking.

\section{Theoretical Framework}

Role of citizens in good governance can be measured through a dependent variable and independent variable.
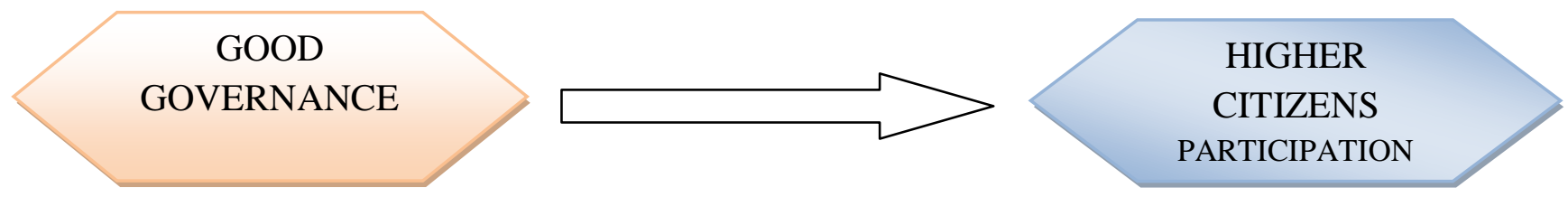


\section{Independent Variable}

In this scenario, independent variable would be "higher citizen participation" as we want to measure the role of citizens in good governance which should result in higher quality of life in the community.

\section{Dependent Variable}

The dependent variable in this scenario would be "good governance" because we want to measure that to what extent higher citizens' participation can lead to good governance.

\section{Research Methodology:-}

Quantitative Research

In order to get the subjects of this research, a mirror questionnaire survey was conducted from the youth and adults. The questions and their options were coded with adequate numbers for data processing.

\section{Hypotheses}

The following hypothesis is formulated for this research:

Hypothesis I:

Ho: Higher participation of citizens implies better governance and should result in higher quality of life in the community

$\mathbf{H}_{\mathrm{A}}$ : Higher participation of citizens doesn't imply better governance and should not result in higher quality of life in the community

\section{Hypothesis II:}

Ho: Awareness and knowledge about citizen's rights are associated with good governance

$\mathbf{H}_{\mathrm{A}}$ : Awareness and knowledge about citizen's rights are not associated with good governance

\section{Hypothesis III:}

Ho: Blind trust of citizens in public officials and extreme satisfaction with the government's ability to solve problems negatively affects governance

$\mathbf{H}_{\mathrm{A}}$ : Blind trust of citizens in public officials and extreme satisfaction with the government's ability to solve problems doesn't negatively affect governance.

\section{Research Design}

Sample Design:

The population of interest chosen for research was both men and women who take keen interest in public policy and issues related to governance.

\section{Data Collection Method:}

For collecting the data, survey research was done. A questionnaire was made which consisted of the closed-ended questions which will be mentioned further along with their results. In the questions options were given in which the respondents had to choose one answer. Data was collected through online questionnaire.

\section{Nature of the Study:}

The research done is descriptive research. The data that was collected and analysis was done of quantitative data. The variables that were set were studied through the questionnaire.

\section{Unit of Analysis and Sampling Procedure:}

The target audience that was set consisted of both men and women who were above the age of 18 and were mostly active citizens who had thorough knowledge about governance and are literate. Sample size of 1000 people was set through convenience sampling approach.

\section{Limitations}

1. As our study is based on the sample size of mere 1000 respondents, we cannot be certain about the interests of the rest of the population which is in billions. There may be parts of the population that does not support citizen participation. 
2. Another issue present is that the matter of geographical proximity, as there are just 1000 respondents chances are that a lot of geographical areas might be missed.

3. A major restriction to our study was that it was conducted on social media which means only literate people (those who can read and write English) could have answered and the respondents were mostly teenagers or midaged people.

4. The research is an attempt to establish a platform for further detailed and larger research project.

5. There are chances present that some of the respondents did not respond honestly to our questions, because of which the results of our study can be affected.

\section{Findings}

The questions asked along with their results are as follows:

\begin{tabular}{|c|c|c|c|c|c|}
\hline \multicolumn{6}{|l|}{ For Q1 to Q15: } \\
\hline 5. 4. Agree(A) & 2. Disagre & (D) & $\begin{array}{r}\text { 1.Strong } \\
\text { Stro }\end{array}$ & $\begin{array}{l}\text { Disagre } \\
\text { ly Agree }\end{array}$ & \\
\hline & 1 & 2 & 3 & 4 & 5 \\
\hline & SD & $\mathrm{D}$ & $\mathrm{U}$ & A & SA \\
\hline $\begin{array}{l}\text { 1. Transparency and accountability of government is not } \\
\text { attainable unless citizens participate in governance } \\
\text { process. }\end{array}$ & $1.7 \%$ & $3.4 \%$ & $6.8 \%$ & $44 \%$ & $44.1 \%$ \\
\hline $\begin{array}{l}\text { 2. Deliberative and participatory models offer great } \\
\text { ways of political decision making. }\end{array}$ & $3.4 \%$ & - & $18.6 \%$ & $59.3 \%$ & $18.7 \%$ \\
\hline $\begin{array}{l}\text { 3. Illiteracy, political naivety and insufficient } \\
\text { mechanisms are the main challenges to incorporate } \\
\text { citizen participation in the governance process. }\end{array}$ & - & $1.6 \%$ & $11.9 \%$ & $49.2 \%$ & $37.3 \%$ \\
\hline $\begin{array}{l}\text { 4. Higher citizen participation makes it difficult for } \\
\text { politicians to make decision beneficial for all the } \\
\text { communities. }\end{array}$ & $3.4 \%$ & $28.8 \%$ & $18.6 \%$ & $39 \%$ & $10.2 \%$ \\
\hline $\begin{array}{l}\text { 5. Decentralization is a way of enhancing the } \\
\text { effectiveness of citizen's participation in local } \\
\text { government. }\end{array}$ & - & $3.3 \%$ & $32.2 \%$ & $49.2 \%$ & $15.3 \%$ \\
\hline $\begin{array}{l}\text { 6. Information and knowledge about citizen's rights } \\
\text { guaranteed by the Constitution play a key part in } \\
\text { good governance. }\end{array}$ & $1.7 \%$ & $3.4 \%$ & $8.5 \%$ & $52.5 \%$ & $33.9 \%$ \\
\hline $\begin{array}{l}\text { 7. Citizen with higher educational attainment are more } \\
\text { likely to question petty and routine corruption of } \\
\text { government than persons with lower educational } \\
\text { attainment. }\end{array}$ & & $3.4 \%$ & $22 \%$ & $37.3 \%$ & $37.3 \%$ \\
\hline $\begin{array}{l}\text { 8. Awareness programs should be held for the citizens } \\
\text { on their active role and participation in national } \\
\text { matters to promote good governance. }\end{array}$ & - & $8.5 \%$ & - & $33.9 \%$ & $57.6 \%$ \\
\hline $\begin{array}{l}\text { 9. Casting a vote upon the basis of relationship/caste } \\
\text { and creed instead of merit may lead to bad } \\
\text { governance. }\end{array}$ & $1.7 \%$ & $5.1 \%$ & $8.5 \%$ & $16.9 \%$ & $67.8 \%$ \\
\hline $\begin{array}{l}\text { 10. The greater the levels of satisfaction and trust with } \\
\text { public officials, the less the perceived need to monitor } \\
\text { governance and vice versa. }\end{array}$ & $5 \%$ & $11.9 \%$ & $22 \%$ & $47.5 \%$ & $13.6 \%$ \\
\hline
\end{tabular}

\section{Discussion:-}

Following is the detailed discussion regarding the respondents reply about the role of citizens' participation in good governance of Pakistan

1. The result shows that more than $88 \%$ of the people are either strongly agree or agree with the statement that transparency and accountability of government is not attainable unless citizens participate in governance 
process. However, $6.8 \%$ people were neutral, $3.4 \%$ people disagree and only $1.7 \%$ people strongly disagree to the statement.

2. $59.3 \%$ people agree that deliberative and participatory models offer great ways of political decision making. There is an equal percentage of people who strongly agree and who were neutral to it i.e. $18.6 \%$, and only $3.4 \%$ people strongly disagree with the above statement

3. Majority of the respondents i.e. $37.3 \%$ people strongly agree and $49.2 \%$ people agree with the statement that illiteracy, political naivety and insufficient mechanisms are the main challenges to incorporate citizen participation in the governance process and only $11.9 \%$ people were neutral and $1.6 \%$ was disagree.

4. $10.2 \%$ people strongly agree and $39 \%$ people agree that higher citizen participation makes it difficult for politicians to make decision beneficial for all the communities, $18.6 \%$ people were neutral, $28.8 \%$ people disagree and only $3.4 \%$ people disagree with the above statement.

5. $15.3 \%$ of the people strongly agree and $49.2 \%$ people agree that decentralization is a way of enhancing the effectiveness of citizen's participation in local government also a huge respondents, 32.2\% people were remain neutral.

6. $33.9 \%$ people strongly agree and $52.5 \%$ people agree with the statement that information and knowledge about citizen's rights guaranteed by the Constitution play a key part in good governance, while $8.5 \%$ people were neutral, $3.4 \%$ people disagree and only $1.7 \%$ people strongly disagree.

7. There is an equal percentage of people who strongly agree and agree with the above statement i.e. $37.3 \%$ respectively and $22 \%$ of the people were neutral to the statement that citizen with higher educational attainment are more likely to question petty and routine corruption of government than persons with lower educational attainment.

8. $57.6 \%$ people strongly agree and $33.9 \%$ people agree that awareness programs should be held to promote active citizen participation.

9. Majority of the respondents i.e.67.8\% strongly agreed, $16.9 \%$ people agree, $8.5 \%$ people were neutral about it, $5.1 \%$ people disagree and only $1.7 \%$ people strongly disagree that casting a vote based on caste and creed leads to bad governance.

10. $13.6 \%$ people strongly agree, $47.5 \%$ people agree, $22 \%$ people were neutral and $11.9 \%$ people disagree with the statement that the greater the levels of satisfaction and trust with public officials, the less the perceived need to monitor governance and vice versa..

\section{Result:-}

In the end, the discussion reveals the result of the survey that proves the hypothesis accepted that higher participation of citizens implies better governance and result in higher quality of life in the community. Awareness and knowledge about citizen's rights are associated with good governance. Citizens who are aware of their rights can lead the government to perform well. Highly educated citizens are the most influential factor in achieving good governance.

Blind trust of citizens in public officials and extreme satisfaction with the government's ability to solve problems negatively affects governance. When citizens show contentment with each and every action of government whether right or wrong, then government officials take advantage of it and misuse their power.

On the basis of our data analysis, we have found that all three of our null hypotheses were accepted and the alternate hypotheses were rejected.

\section{Conclusion:-}

Results show that without the participation of people, good governance cannot be achieved Majority of the public think that their participation is necessary to achieve transparency and accountability in governance. Participation of citizens in government can help government to come up with more ideas and solutions. Countries where participatory models are exercised enjoy the trust and support of their citizens which contribute towards betterment of the country. However, anything that exceeds its limit do more harm than good. Similarly, too much interference of citizens in governmental affairs sometimes creates hurdles for public officials to make a decision beneficial for all the communities. So, balance is the key to achieve good governance.

Major factors that hinder citizen participation in governance process are illiteracy, political naivety and insufficient mechanisms. When citizens are indifferent towards their rights provided by constitution, the government becomes 
despotic. That's why educated people are more likely to contribute in governance process because they are aware of their rights and duties. Being aware of the rights and responsibilities is an important part in good governance.

Findings also showed that casting a vote upon the basis of relationship/caste and creed instead of merit lead to bad governance. Instead; vote must be casted on the basis of the capability and competency of the individuals. When people elect the government based on ethnicity/caste, they trust them blindly and do not keep an eye on them. Extreme satisfaction with each and every action of government is bad. Though supporting government is important, but keeping it accountable is must.

\section{Recommendations}

Although our sample size was small, but based on the responses of the respondents, we can clearly see that majority of the population believe that citizen participation must be incorporated in governance process hence, following are few steps that can be taken to ensure that.

1. Government should create the scope for developing the capacity of people to come forward with their decisions and resources to implement development programs jointly.

2. Awareness campaigns should be held by NGOs to make the citizens aware about their role in governance process and to motivate them to participate in governance.

3. Education is crucially important for all the citizens. With better education people's voting preferences get better bases. Illiteracy must be eliminated from society.

4. Besides being aware of their rights, citizens must also be aware of their duties. To keep the government noncorruptible, citizens must also be honest.

\section{References:-}

1. APSC [Australian Public Service Commission], 2007. Changing Behaviour: a public policy perspective, http://www.apsc.gov.au/publications07/changingbehaviour.pdf

2. Arnstein, S. 1971. 'Eight Rungs on the Ladder of participation', in E. Cahn, et al. Citizen Participation: Effecting Community Change, Praeger, London.

3. Aulich, C. 1999. 'From Convergence to Divergence: Reforming Australian Local Government', Australian Journal of Public Administration, vol. 58(3), pp. 12-23.

4. Aulich, C. 2005. 'Australia: Still a Tale of Cinderella?', in B. Denters, and L. Rose (eds), Comparing Local Governance: Trends and Developments, Palgrave Macmillan, Basingstoke.

5. Caddy, J. and C. Vergez, 2001. Citizens as Partners: Information, Consultation and Public Participation in Policy Making, OECD, Paris.

6. Curtain, R. 2003. 'What Role for Citizens in Developing and Implementing Public Policy?', in NIG [National Institute for Governance], Facing the Future: Engaging stakeholders and citizens in developing public policy, NIG, University of Canberra, Canberra.

7. Curtain, R. 2006. 'Citizens can solve wicked problems', in H.E. Colebatch (ed.), Beyond the Policy Cycle, Allen and Unwin.

8. Cuthill, M. and J. Fien, 2005. 'Capacity Building: Facilitating Citizen participation in Local Governance', Australian Journal of Public Administration, vol. 64(4), pp. 63-80.

9. Dahl, R. A. 1994: A Democratic Dilemma. System Effectiveness versus Citizen Participation, in: Political Science Quarterly 10: 1, 23-34.

10. David Levi-Faur, "Regulation \& Regulatory Governance", in David Levi-Faur, Handbook on the Politics of Regulation, Edward Elgar, Cheltenham, 2011, pp. 1-20.

11. Davis, G. 2001. 'Government by Discussion', in P. Botsman, and M. Latham (eds), The Enabling State: People Before Bureaucracy, Pluto Press, Sydney.

12. Dawkins, J. 2003. 'New Kinds of Networks for Policy making Besides Government', in NIG [National Institute for Governance], Facing the Future: Engaging stakeholders and citizens in developing public policy, NIG, University of Canberra, Canberra.

13. Geddes, M. 2005. 'International Perspectives and Policy Issues', in P. Smyth, T. Reddel and A. Jones (eds), Community and Local Governance in Australia, UNSW Press, Sydney.

14. Genoff, R. 2005. 'A Case Study in the New Regionalism', in P. Smyth, T. Reddel and A. Jones (eds), Community and Local Governance in Australia, UNSW Press, Sydney.

15. Grimble, R./ Man-Kwun Chan, 1995: Stakeholder analysis for natural resource management in developing countries: Some Practical guidelines for making management more participatory and effective, in: Natural Resources Forum, Vol. 19, No. 2, 113-124. 
16. Joerges, C./Neyer, J. 1997: From Intergovernmental Bargaining to Deliberative Political Processes: The Constitutionalisation of Comitology, in: European Law Journal, Vol. 3, 273-299.

17. Kooiman, J. Governing as Governance. Sage publications 2003. p. 170.

18. Lindblom, C. 1965: The Intelligence of Democracy. Decision making through mutual adjustment, New York

19. Martin, J. 2006. 'Government and Community Engagement', Paper for the Tenth International Research Symposium on Public Management, Glasgow, 10-12 April.

20. Pharr, S. and R. Putnam, 2000. Disaffected Democracies: what's troubling the trilateral countries?, Princeton University Press, Princeton.

21. Pierre, J./ Peters B.G. 2000: Governance, Politics and the State, Basingstoke.

22. Putnam, R. 2000. Bowling Alone: the Collapse and Revival of the American Community, Simon and Schuster, New York.

23. Queensland Government, 2001. Smart State - investing in people and communities, GoPrint, Brisbane.

24. Rainnie, A. 2005. 'Regional development Policy and Social Inclusion', in P. Smyth, T. Reddel, and A. Jones (eds), Community and Local Governance in Australia, UNSW Press, Sydney.

25. Reddel, T. and G. Woolcock, 2003. 'A Critical Review of Citizen Engagement Strategies in Queensland', in NIG [National Institute for Governance], Facing the Future: Engaging stakeholders and citizens in developing public policy, NIG, University of Canberra, Canberra.

26. Richardson, A. 1983. Participation, Routledge and Kegan Paul, London.

27. Security Sector Governance, SSR Backgrounder Series. Geneva: Geneva Centre for the Democratic Control of Armed Forces (DCAF). 2015.

28. Self, P. 1997. 'The Future of Local Government', in N. Marshall, and B. Dollery (eds), Australian Local Government: Reform and Renewal, Macmillan, Melbourne.

29. Sharp, E. 1980. 'Towards a New Study of Urban Services and Citizen Participation ', Midwest Review of Public Administration vol. 14(2), pp. 105-118.

30. Stoker, G. 1998. 'Governance as theory: five propositions', International Social Science Journal, vol. 155, pp. 17-28.

31. Stoker, G. 2004. Transforming Local Governance, Palgrave Macmillan, Basingstoke.

32. 'Triumph, Deficit or Contestation? Deepening the 'Deepening Democracy' Debate'Institute of Development Studies (IDS) Working Paper 264 July 2006.

33. Waheduzzaman, 2010 "Value of people's participation for good governance in developing countries", Transforming Government: People, Process and Policy, Vol. 4 Issue: 4, pp.386402, https://doi.org/10.1108/17506161011081345

34. Williamson, Oliver E. 1979 "Transaction-Cost Economics: The Governance of Contractual Relations," Journal of Law and Economics: Vol. 22: No. 2, Article 3|accessible at: http://chicagounbound.uchicago.edu/jle/vol22/iss $2 / 3$

35. Wiseman, J. 2006. 'Local Heroes? Learning from Recent Community Strengthening Initiatives in Victoria', Australian Journal of Public Administration, vol. 65(2), pp. 95-107.

36. World Bank, Managing Development - The Governance Dimension, 1991, Washington D.C., p. 1

37. "World Governance Index 2009 Report". World Governance. Archived from the original on 4 October 2011. Retrieved 3 February 2013. 